\title{
WHOLESALE PRICING IN A SMALL OPEN ECONOMY**
}

\author{
BY
}

JAN VAN DALEN AND ROY THURIK*

\section{INTRODUCTION}

One of the capturing features of wholesale pricing is the active involvement of wholesale merchants in the pricing process in all kinds of commodity markets throughout the economy; and since, as noted by Beckman and Engle (1949), 'it is on these markets that wholesale prices are determined (...), the wholesaling structure is essentially the price-determining sector of the economic system' (p. 604). The indusputably important economic role of wholesaling sharply contrasts with the paucity of fundamental research into wholesale pricing or indeed into any other aspect of wholesaling.

The empirical analysis of wholesale pricing encounters various problems. Adequate wholesale statistics are rare, wholesale merchants themselves tend to be reluctant to accept results of scientific research, and discrepancies in operational definitions are still of the kind that effectively obstruct even the simplest comparative study of the wholesaling structure in EU member states. Moreover, the prominent role of personal interactions in wholesale distribution cause an 'antiexact, anti-causal sphere' (Van de Woestijne, 1982, p. 21) which makes wholesaling less attractive, and a priori less suitable for quantitative research. A more fundamental problem stems from the service character of wholesale production: wholesale merchants do not generate a physical product (as manufacturers do), but instead provide a 'bundle of services' enabling the efficient distribution of commodities between sellers and buyers (as retailers do, cf. Nooteboom, 1980). This feature immediately affects the interpretation and measurement of all productrelated concepts, such as market and market concentration, competition and competitors, product differentiation and price. For example, competition in wholesaling cannot simply be confined to other businesses selling similar commodities,

* Erasmus University, Rotterdam, The Netherlands.

** The authors gratefully acknowledge extensive criticisms by Johan Koerts and Arjen van Witteloostuijn and research assistance by Michiel Eijkhout who also co-authored earlier research reports. The Central Bureau of Statistics is acknowledged for providing access to their census data of the Dutch wholesale trade. Remaining errors are as usual the sole responsibility of the authors. 
but extends to all businesses performing tasks typically belonging to the wholesale service package, such as buying and selling, inventory keeping, transport, market coverage, providing a convenient assortment, bulk breaking and offering credit. The service character of wholesaling together with the absence of quantitative information about the services provided by economic agents other than the wholesale merchant implies that neither the actual size of wholesale markets nor the share of the wholesale trade therein can ever be measured accurately.

The aforementioned problems colour our research objective which is to shed light on the peculiarities of wholesale pricing by empirically analyzing variations in wholesale profit margins between types of wholesale trade. The empirical framework combines the behavioural mark-up approach to pricing with traditional hypotheses about industry pricing. The resulting model secures the flexibility and intuitive appeal of the mark-up approach, while simultaneously employing the vast amount of insights into pricing in imperfectly competitive surroundings. The model is estimated using a large body of census data covering the entire Dutch wholesale sector, 1986. The paper is structured as follows. Section 2 sets out the empirical framework. Section 3 discusses sources of variations in wholesale margins. Section 4 presents the empirical results and section 5 concludes the paper.

\section{THE EMPIRICAL FRAMEWORK}

The theoretical background of our pricing study is made up of two widespread beliefs about the price behaviour of commercial businesses. The first, which is maintained in traditional industrial pricing studies, attributes variations in industry profit rates (performance) to differences in competitive conditions from one industry to another (structure), together with the pricing strategies (conduct) of firms within industries (see Martin, 1988; Scherer and Ross, 1990; and Waterson, 1984, among others). In this view, markets are assumed to be imperfectly competitive as a result of scale economies, product differentiation, imperfect information and other conditions, offering firms opportunities to raise selling prices over marginal costs and to incur business profits above the 'normal' level associated with competitive pricing. Empirical applications of this view are frequently found in the area of manufacturing pricing and have been extensively surveyed by Cubbin (1988) and Schmalensee (1989).

Opposed to this view is the belief that firms do not attempt to maximise their business profits at all, but instead set prices according to some rule of thumb usually a variant of cost-plus pricing. This behavioural type of pricing was first advocated by Hall and Hitch (1939) and was subsequently modified into various directions: normal cost pricing (Andrews, 1949), administered cost pricing (Means, 1962) and wholesale cost mark-up pricing (Cyert and March, 1963). In addition, the concept of full-cost pricing has proven to be particularly useful to the empirical analysis of retail margins (see Nooteboom, 1980, 1985; and 
Nooteboom and Thurik, 1985), where it is assumed that gross retail margins emerge as unit operational retail costs plus a profit mark-up which 'provides both an income from shopkeeper's labour and a reward for investment and entrepreneurship' (Nooteboom, 1985, p. 650).

It is not our aim to confront both approaches and to spell out all (theoretical) differences; such has been sufficiently done elsewhere (see Silberston, 1970; Koutsoyiannis, 1980; Van Witteloostuijn, 1988; and others). Instead, elements from both pricing theories are combined in an attempt to reconcile both approaches at the empirical level. A behavioural formalisation of wholesale pricing inspired by Nooteboom's (1985) full-cost model of retail margins, is to let trade margins emerge as an additive mark-up on percentage operating costs:

$$
\mu=\alpha_{1} \kappa_{L a b}+\alpha_{2} \kappa_{R e m}+\pi_{\mu}(X)
$$

where $\mu$ is the average wholesale margin measured as the difference between industry sales $Q$, and purchases $I$, divided by sales; $\kappa_{L a b}$ represents the percentage of labour costs measured as the share of labour costs (excluding the rewards of owner-managers) in total sales; $\kappa_{\text {Rem }}$ reflects the percentage of remaining operating costs which cover expenses for housing, machines, transport, selling and insurances; and $\pi_{\mu}$ summarizes the market and trade characteristics $X$, which influence industry profit rates. The distinction between labour costs and remaining operating expenses has been made to emphasize the labour-intensive nature of wholesaling, to increase the flexibility of the mark-up specification and to facilitate comparisons with previous empirical and theoretical studies of labour productivity in retailing and wholesaling ( $c f$. Nooteboom, 1982, 1987; Thurik, 1984, 1986; and Van Dalen et al., 1990, 1991). Moreover, the parameters $\alpha_{1}$ and $\alpha_{2}$ provide a test of the mark-up hypothesis. If the $\alpha$ 's differ significantly from one, the corresponding cost categories affect net returns on sales thereby jeopardizing the mark-up hypothesis; such may occur, for example, when trade costs are partly sunk thereby affecting both operating expenses and price behaviour of wholesale businesses (cf. Baumol and Willig, 1981, and Baumol et al., 1982; see Van Witteloostuijn, 1992, for a review). On the other hand, if the $\alpha$ 's do not differ significantly from one, the mark-up hypothesis is maintained and $\pi_{\mu}$ may be interpreted as the net profit rate.

A traditional formalisation of wholesale pricing is to directly relate some measure of the price-cost margin $\rho$ to determinants of market structure, entry barriers and growth:

$$
\rho=\pi_{\rho}(X)
$$

There is little consensus about the proper measurement of the price-cost margin. Some authors following Bain (1951), measure $\rho$ by the ratio of net profits after taxes to stockholder's equity (e.g. Comanor and Wilson, 1967, p. 427; Esposito 
and Esposito, 1971, p. 345; and Caves et al., 1975, p. 137), whereas others, following Collins and Preston $(1967$, p. 286), measure $\rho$ by the ratio of value-added at factor costs minus payroll to total sales (e.g. Strickland and Weiss, 1976, p. 1111; De Ghellinck et al., 1988, p. 7). ${ }^{1}$ The latter receive theoretical support as far as the denominator of $\rho$ is concerned - from Cowling and Waterson (1976) who demonstrate that the industry price-cost margin may be arrived at as the ratio of revenues minus marginal costs to industry revenues. However, this definition is still a theoretical one with little empirical content, since the use of marginal costs formally requires insights into actual industry cost structures. The practice to approximate marginal costs by labour costs or by total operating expenses only makes sense when fixed costs are negligible and marginal costs are constant for the range of output considered (which is difficult to maintain for Dutch wholesaling; $c f$. Van Dalen et al., 1990, who show that notable scale economies associated with minimum labour requirements exist, the importance of which is emphasized by the small business character of Dutch wholesaling). Leaving these problems aside, we shall measure $\rho$ by the gross trade margin minus labour costs and remaining operating expenses divided by sales, $\left(Q-I-K_{L a b}-K_{R e m}\right) / Q$. In doing so, the price-cost model (2) may be viewed as a special case of the mark-up model (1) through proper restrictions on $\alpha_{1}(=1)$ and $\alpha_{2}(=1)$. In this special case, the net profit rate $\pi_{\mu}$ will be equal to $\pi_{\rho}$.

The two empirical approaches to industry pricing have been further integrated by decomposing the labour costs and operating costs in model (1) into fixed and variable costs, where fixed costs have been defined as the share of costs not depending on the level of sales. ${ }^{2}$ The mark-up relation is reformulated to allow for the separate influences of fixed and variable costs in the following manner:

$$
\mu=\alpha_{1}\left(\kappa_{L a b}-\bar{\kappa}_{L a b}\right)+\alpha_{2}\left(\kappa_{R e m}-\bar{\kappa}_{R e m}\right)+\alpha_{3} \bar{\kappa}_{L a b}+\alpha_{4} \bar{\kappa}_{R e m}+\pi_{\mu}(X)
$$

where $\bar{\kappa}_{L a b}$ and $\bar{\kappa}_{\text {Rem }}$ represent the fixed labour and remaining operating costs, respectively. If prices are set as a mark-up on direct operational costs (i.e.,

1 Many variations occur. For instance, Chou (1986, p. 432, p. 436) employs the ratio of the production value minus intermediate expenses and payroll to sales; while Domowitz et al. (1986, p. 4) use the same numerator but divide by the production value (i.e. sales plus increase in inventories). Moreover, Khalilzadeh-Shirazi $(1974$, p. 67) uses the ratio of sales minus all direct and overhead costs except interest and depreciation, while Pagoulatos and Sorenson (1976, p. 257) subtract depreciation as well. Hutchinson (1981, p. 255), finally, remains rather vague about his measure using value-added minus payroll divided by 'gross output' which has not been defined and may indeed be measured in various ways. Needless to add that the existence of so many measures of performance seriously hampers the comparability of empirical results.

2 Fixed costs were not available in the dataset. They have been estimated for each type of trade by means of auxiliary regressions of labour and operating costs on sales using the original firm-level data. The industry fixed costs follow as the estimated intercepts. The implied linear relationships represent approximations to possibly more complex non-linear cost structures and do, of course, not reflect the theoretical cost relations. 
$\alpha_{1}=\alpha_{2}=1$ and $\alpha_{3}=\alpha_{4}=0$ ) our model can be viewed as an empirical representative of the theoretical price-cost model. If, however, all $\alpha$ 's are equal to one, the original mark-up model is obtained. Model (3) broadly defines the empirical framework of our pricing analysis. More specific hypotheses regarding the undefined sources of profit variations summarized by $X$, are the subject of the following section.

\section{SOURCES OF VARIATIONS IN WHOLESALE PROFIT RATES}

The discussion of the causes of variations in wholesale profit rates is again inspired by the two streams of literature: traditional performance studies stressing the influences of market structure (concentration, product differentiation, cost advantages, etc.) and conduct (collusion and strategic behaviour); and behavioural, notably retail, pricing studies emphasizing the role of the entrepreneurial reward. The influences of inventories and international trade are discussed separately in view of their importance in wholesaling.

\subsection{Concentration, Product Differentiation and Other Barriers to Entry}

The relationship between market concentration and industry profit rates predominates the empirical literature of industry performance. The basic proposition in these studies is that firms in concentrated industries are in a better position to raise prices over marginal costs than firms in unconcentrated industries. Empirical elaboration of this proposition encounters four difficulties at least. First and most fundamentally, the service character of wholesale production makes the 'market for the wholesale product' a diffuse concept: neither the actual size of wholesale markets nor the share of the wholesale trade therein can be measured accurately. Any concentration measure based on the relative sizes of wholesale transactions will overstate actual market concentration. Secondly, The Netherlands are an open economy which necessitates the correction of the concentration measure for exports (see Glejser et al., 1980; Lyons, 1981); the influence of competing imports is taken into account through its cross-effect with the market concentration measure as will be explained below. Thirdly, the comparability of concentration measures of different wholesale industries is limited, because these industries consist of largely varying numbers of firms (cf. Phillips, 1976). This problem is solved by scaling the range of possible outcomes of the (Herfindahl) concentration measure (of which the lower bound depends on the number of firms within the industry) between zero and one. Fourthly, in accordance with Stigler's (1964) market-power hypothesis, the effectiveness of collusion is likely to be greater when industries become increasingly concentrated suggesting a nonlinear, progressive, relationship between concentration and performance ( $c f$. Collins and Preston, 1966; and formal derivations by Cowling and Waterson, 1976; Geroski, 1981; Clarke et al., 1984; and Stålhammer, 1991). In the present 
study this non-linearity is accounted for by dividing the concentration measure by one minus itself. The resulting transformed concentration measure $H H$, is expected to have a positive influence on wholesale profit margins.

Three other traditional explanations of imperfect price behaviour are based on advertising intensity, capital intensity and minimum efficient scale, assuming these factors contribute effectively to the raising of entry barriers. The advertising intensity $A S$, measured by the ratio of advertising and other selling costs to sales, is viewed as a way to differentiate the wholesale service package and, accordingly, is expected to have a positive influence on trade margins. The assumed influence of capital intensity $C I$, measured by the ratio of capital costs (rents and depreciation costs) to sales, is, however, less straightforward in the field of wholesaling. Firstly, the amount of capital needed to enter wholesale markets is usually small, while the nature of capital requirements is to a large extent 'general purpose.' Secondly, the openness of the economy makes it difficult to retard foreign entry on the basis of capital requirements; foreign sellers are actually likely to supply at more competitive terms than capital-intensive domestic traders in view of their ability to secure scale economies in their home markets. Moreover, this openness makes capital-intensive firms particularly viable to excess capacity situations, as predicted by De Ghellinck et al. (1988). Taken together, these arguments suggest a negative rather than a positive influence of the capital intensity on wholesale margins. Lastly, the minimum firm size for the efficient operation of wholesale tasks $M E S$, measured by the average employment in the firms that account for the upper $50 \%$ of total employment in each wholesale industry ( $c f$. Comanor and Wilson, 1967; and Caves et al., 1975), may obstruct potential competitors from entering the wholesale market and enable incumbents to set less competitive prices. This familiar explanation may be questioned for the same reasons that hold against the traditional explanation of the capital-intensity effect.

\subsection{International Trade}

Dutch wholesale merchants are actively involved in international trade: the wholesale shares in gross imports and exports are both equal to about $40 \%$. The influence of exporting and importing on trade margins is studied from two perspectives: product differentiation and channel organization. In the case of exporting, the export intensity $E X$, measured by the ratio of industry exports to sales, is viewed as a way to differentiate the wholesale product. Estimates of its effect on profit margins are, however, rarely concordant and often contradictory. ${ }^{3}$ In the

3 A fine example of conflicting estimates of the impact of exports is given by Pagoulatos and Sorenson (1976). Their Table 1 reports a negative influence of exports on the price-cost margin in manufacturing for four EC countries: Belgium, France, Italy, and Germany, whereas a positive infiuence is reported for The Netherlands. Positive signs are also presented by, for example, KhalilzadehShirazi (1974, p. 72) for UK manufacturing and Hutschinson (1981, pp. 256-257) for Irish manufac- 
case of Dutch exporters, a negative influence is expected, since they generally sell in competitive EU markets with elastic demand where the gain by selling abroad is offset by the costs of transportation. In addition, the wholesale export share $E X_{M}$, measured by the share of industry exports in the total Dutch exports of a particular merchandise, is interpreted as an indicator of channel organization. Its effect on trade margins is indeterminate. A positive effect results, if the export market share can be associated with market power, whereas a negative effect results if high export shares are indicative for substantial export risks, in which case manufacturers and other businesses leave export activities to specialized wholesale merchants.

The influence of importing is analyzed with the aid of the import intensity $I M$, measured by the ratio of the import value to total purchases, and the share of competing imports in the total Dutch import of a certain kind of merchandise $I M_{C}$. A distinction between the two is necessary since - unlike in manufacturing where imports constitute a competitive threat - importing by wholesalers is inherently part of the service package and provides a means to escape from competitive price setting either through the appeal of foreign goods on domestic markets (making demand less elastic) or through exclusive selling contracts with foreign suppliers. Imported goods constitute a source of competition only in so far as they are imported by other market participants. Accordingly, we expect the influence of the import intensity to be positive and that of competing imports to be negative ( $c f$. Esposito and Esposito, 1971; Khalilzadeh-Shirazi, 1974; Pagoulatos and Sorenson, 1976; Marvel, 1980; and Hutchinson, 1981; see Caves, 1985 for a survey). Furthermore, the influence of competing imports can be assumed to depend on the competitive structure of home markets. Following Pugel (1978) and Jacquemin et al. (1980), the impact of competing imports on wholesale profit rates will be more acutely felt in comparatively concentrated markets, while it will be negligible in unconcentrated markets. This conditional influence of competing imports is represented by its cross product with market concentration, $I M_{C} \times H H^{4}$; it is expected to have a negative influence on wholesale profit rates.

\subsection{Inventories}

Studies of the influence of inventories on pricing invariably assume the keeping of inventories to be motivated by a firm's desire to cope with unexpected demand fluctuations on the one hand and to avoid costly changes in production schedules on the other (see Mills, 1957, p. 222; and various formalisations, like

turing industries. Negative effects are reported, among others by Chou (1986, pp. 438-439) for Taiwan and by Prince and Thurik (1992, p. 392) for low-concentrated, consumer goods industries in The Netherlands.

4 A similar functional form is used, for instance, in the empirical work of Domowitz et al. (1986). A formal derivation of the joint influence of market concentration and competing imports on aggregate performance is given in a recent article by Stålhammer (1991). 
those in Blinder, 1982, 1986; Reagan, 1982; Amihud and Mendelson, 1983; Ashley and Orr, 1985; Blanchard, 1983; West, 1986; Eichenbaum, 1984; Abel, 1985; and Kahn, 1987). However, these theories have limited value for understanding wholesale pricing as they apply to price and inventory decisions of manufacturers, for whom 'inventories are primarily a by-product of production' (Hay, 1972, p. 408). Wholesale merchants, by contrast, are not involved in physical production, but in the transformation of orders and, consequently, the assumption that inventories are kept to avoid costly production changes cannot be maintained in the explanation of wholesale pricing. Instead, inventory keeping is a primary task of wholesale traders which enhances the product of wholesaling in various ways. Adequate inventory policy may therefore be expected to reduce the elasticity of the demand for wholesale services and to have a positive influence on wholesale profit rates. At the same time inventories affect the costs of distribution via substantial investments in storage capacity, merchandise and risks of obsolescence and damage, requiring suitable compensation through net returns. Consequently, the average stock duration $V,{ }^{5}$ which mirrors the importance of inventory keeping in the wholesale service package, is expected to have a positive influence on profit rates.

In addition, attention is paid to the dynamic and strategic aspects of inventories. Firstly, inventories may be kept to catch up with fluctuations in the business cycle, represented by the annual change in inventory levels $\Delta V$. Accumulation of inventories is likely to occur in periods of slack demand, which will be accompanied with tight wholesale margins in view of the increased pressure on selling prices in combination with higher inventory costs: a negative effect of inventory increases is therefore expected. Secondly, the keeping of inventories may serve strategic purposes. Inventories may, just like excess capacity, constitute a retaliatory threat thereby raising barriers to entry and restraining incumbent firms from cutting prices (Rosenbaum, 1989, p. 235). Inventories thus support the collusive behaviour among firms and the more so when demand is high and the incentives to resort to price cuttings are strong (Rotemberg and Saloner, 1989). The interaction between inventories and market structure suggests that the strategic consequences of inventories for wholesale pricing will be small in atomistic industries and will be increasingly felt the more concentrated the wholesale industry is. We shall test this hypothesis by incorporating the cross product of stock duration and market concentration $V \times H H$ which is expected to have a positive effect on wholesale profit rates.

5 See Nooteboom and Thurik (1985) for an application to retail pricing and Rosenbaum (1989) for an application to manufacturing pricing. A serious problem of this measure is that it disregards the variety of functions of wholesale inventories and that it does not distinguish between the productenhancing qualities of inventories, on the one hand, and the actual speed at which inventories pass through the warehouse, on the other. However, attempts to separate the 'quality' and 'duration' aspects have thus far not been satisfactory (see Van Dalen, 1992). 


\subsection{The Entrepreneurial Reward}

The influence of the entrepreneurial reward, finally, is associated with the smallbusiness character of wholesaling (over $80 \%$ of Dutch wholesale businesses employs less than 10 persons). Small-sized wholesale firms are typically managed by the owner whose reward is part of the residual income instead of payroll costs. As a consequence, aggregate wholesale margins vary with the number of independent wholesale merchants in each type of trade and the height of their rewards. Assuming, for convenience that the reward $W_{i}$ of each owner is composed of a fixed, minimum reward $\rho_{1}$ ( $c f$. Nooteboom, 1985) and a variable reward which varies in proportion $\rho_{2}$ with annual turnover, $Q_{i}$, i.e. $W_{i}=\rho_{1}+\rho_{2} Q_{i}$, the share of total entrepreneurial rewards in industry sales may be derived as $W / Q=\rho_{1} R E W_{F i x}+\rho_{2} R E W_{V a r}$, where $R E W_{F i x}$ is the number of owner-managers in the industry and $R E W_{V a r}$ is the sum of annual sales times the number of owners per firm both divided by industry sales (see Van Dalen, 1992). The entrepreneurial reward thus acts as a source of scale economies: when the scale of wholesale activities increases, the share of the minimum reward in turnover decreases, which allows wholesalers to set more competitive prices.

\section{ESTIMATION RESULTS}

The stochastic specification of our model combines a slightly reformulated version of model (3) with the determinants of wholesale profit rates discussed in the foregoing section:

$$
\mu=\alpha_{1} \kappa_{L a b}+\alpha_{2} \kappa_{R e m}+\gamma_{1} \bar{\kappa}_{L a b}+\gamma_{2} \bar{\kappa}_{R e m}+\pi(X)+\epsilon_{\mu}
$$

where $\pi$ is defined as

$$
\begin{aligned}
\pi(X)= & \pi_{0}+\pi_{1} R E W_{F i x}+\pi_{2} R E W_{V a r}+\pi_{3} H H+\pi_{4} I M_{C} \times H H \\
& +\pi_{5} V \times H H+\pi_{6} E X+\pi_{7} E X_{M}+\pi_{8} I M+\pi_{9} I M_{C}+\pi_{10} V \\
& +\pi_{11} \Delta V+\pi_{12} A S+\pi_{13} C I+\pi_{14} M E S
\end{aligned}
$$

and $\epsilon_{\mu}$ is an ordinary disturbance term which is assumed to be identically and independently normally distributed.

The model is estimated using wholesale census data of the Dutch Central Bureau of Statistics, 1986. The observations in the dataset refer to wholesale business types that are defined on the basis of the merchandise provided and the distribution function performed. The latter criterion is operationalised via a wholesaler's functional specialization: transit trade, importing, exporting, selling to domestic manufacturers, to domestic retailers and to other domestic businesses, and wholesale trade without particular emphasis in activities. These seven posi- 
tions in the distribution channel in combination with the eighteen different commodity groups lead to $126(=7 \times 18)$ possible categories of wholesale merchants. Five categories contain no information at all and three categories proved extremely influential (on the basis of Cook's distance) and have been eliminated from further analysis. As a result, our dataset contains information about 118 wholesale business types (or sub-industries). More detailed information can be found in the Data Appendix.

\subsection{Empirical Results}

Table 1 summarizes the estimation results for our pricing model (4) and for the price-cost model; where the results for the latter are obtained after restricting $\alpha_{1}$ and $\alpha_{2}$ to 1 and $\gamma_{1}$ and $\gamma_{2}$ to 0 in (4). Our discussion will focus on the results of our pricing model. The results of the price-cost model have been added to illustrate the impact of eliminating the role of distribution costs and to facilitate future comparisons with the broader pricing literature.

A first glance at the results reveals that the explanatory power of our pricing model is considerable: the $R^{2}$ s are equal to 0.98 for the entire Dutch wholesale trade and to 0.99 and 0.98 for the raw material trade and consumer goods trades, respectively. ${ }^{6}$ Furthermore, a comparison of the regression results for the raw material trade and the consumer goods trade with the aid of Chow tests reveals significant differences in the pricing conduct of both sub-sectors. ${ }^{7}$ This heterogeneity in price behaviour is illustrated by the differing parameter estimates discussed below. Moreover, a comparison of the results of our pricing model with those of the classical price-cost model shows that our model is a better tool to describe wholesale price behaviour than the latter model. ${ }^{8}$

6 These high fits can partly be ascribed to the use of averaged data, which eliminates much of the firm-specific variation, and to the high correlations between gross wholesale margins and percentage operating expenses. The simple correlation coefficients of the gross trade margin and the percentage labour costs are equal to 0.948 for the entire wholesale trade, to 0.955 for the raw material trade, and to 0.926 for the consumer goods trade. Similarly, the correlation coefficients of the trade margin and the remaining operating expenses are equal to $0.885,0.892$, and 0.866 , respectively. However, even after removing the influence of distribution costs (as has been done in the price-cost model), the $R^{2} s$ reach values well over 0.60 implying that the impact of the market and trade characteristics is still considerable.

7 The outcome for the symmetric Chow statistic, Chow $(=1.576)$, in Table 1 implies the rejection (at the 10\% significance level) of the null-hypothesis that the two sub-samples are drawn from one homogeneous sample. Similarly, the value for $\mathrm{Chow}_{1}(=1.790)$ implies the rejection of the hypothesis that the raw material trade is a homogeneous sub-sample of the entire wholesale sector. The outcome for Chow 2 indicates that differences between the consumer goods trade and the entire wholesale sector are negligible. The application of the three Chow tests taken together therefore indicates that raw material traders and merchants selling consumer goods differ with respect to their price behaviour.

8. The appropriateness of the PCM-model is formally tested by examining the joint hypothesis that $\alpha_{1}$ and $\alpha_{2}$ are equal to 1 and $\gamma_{1}$ and $\gamma_{2}$ are both equal to 0 in our pricing model. The resulting $F$-values are equal to $15.846(0.0001)$ for the entire Dutch wholesale trade, $11.386(0.0001)$ for the 


\subsection{Discussion of the Parameter Estimates}

A closer look at the results for the two sub-sectors, shows that the influence of labour costs on trade margins is systematically greater than one $\left(\hat{\alpha}_{1}>1\right)$, while that of remaining operating expenses is smaller than one $\left(\hat{\alpha}_{2}<1\right)$. These findings emphasize the central role of human capital in wholesaling: the personal involvement of entrepreneurs and employees is an important means to differentiate the wholesale product and to enhance profit rates. ${ }^{9}$ Furthermore, little support is obtained for the distinction between the fixed and variable costs of distribution. The significant difference between the fixed and variable labour costs in the case of the entire wholesale trade $\left(\hat{\gamma}_{1}>0\right)$ should be ascribed to the heterogeneity with respect to pricing: it disappears when analyzing the two sub-sectors separately. Summarizing the effects of costs, we find that the classical approach to wholesale pricing is again rejected - since fixed costs do play a role in wholesale pricing and the original full-cost mark-up hypothesis (1) is maintained - since few differences exist between the effects of fixed and variable costs.

In addition, the role of mark-up determinants appears to be more pronounced for the raw material trade than for the consumer goods trade. In the latter case most influences are insignificant; the effects of import intensity, inventory investment and variable entrepreneurial reward excepted. However, the absence of significant results is informative just as well. For instance, the fact that the basic entrepreneurial reward for independent wholesalers is close to zero in both types of trade $\left(\hat{\pi}_{1} \approx 0\right)$ implies that the entrepreneurial reward does not constitute a source of scale effects - unlike in retailing, where basic entrepreneurial rewards about the size of the statutory minimum wage rate are consistently found (see Nooteboom, 1985, among others). Also, the fact that the influence of the minimum efficient scale proves insignificant $\left(\hat{\pi}_{14} \approx 0\right)$ for both types of trade supports our view that it is extremely difficulty to retard entry into wholesale markets through capital-based barriers: firms may effectively enter wholesale markets with a minimum of capital and a limited service package; accordingly, a relationship between the minimum efficient scale and pricing need not be expected. Moreover, the impact of capital intensity, which is smaller than one $\left(\hat{\pi}_{13}<1\right)$ for both sub-sectors, suggests that the costs of capital (rents and depreciation) are not fully passed on to the buyer: capital-intensive wholesalers tend to follow more competitive pricing routines than others (in contrast with labour-intensive traders as noted above). The results so far indicate that wholesale margins emerge indepen-

raw material trade and $5.528(0.0013)$ for the consumer goods trade. The corresponding significances (in parentheses) are all below the $1 \%$-level indicating that the PCM-model is rejected in favour of our pricing model in all three cases.

9 The result may also be caused by a formal link between wages and performance. However, we do not consider this of much importance in our meso-analysis, since it would require all wholesale businesses to remunerate all personnel on the basis of annual profit rates, which is not very likely. 


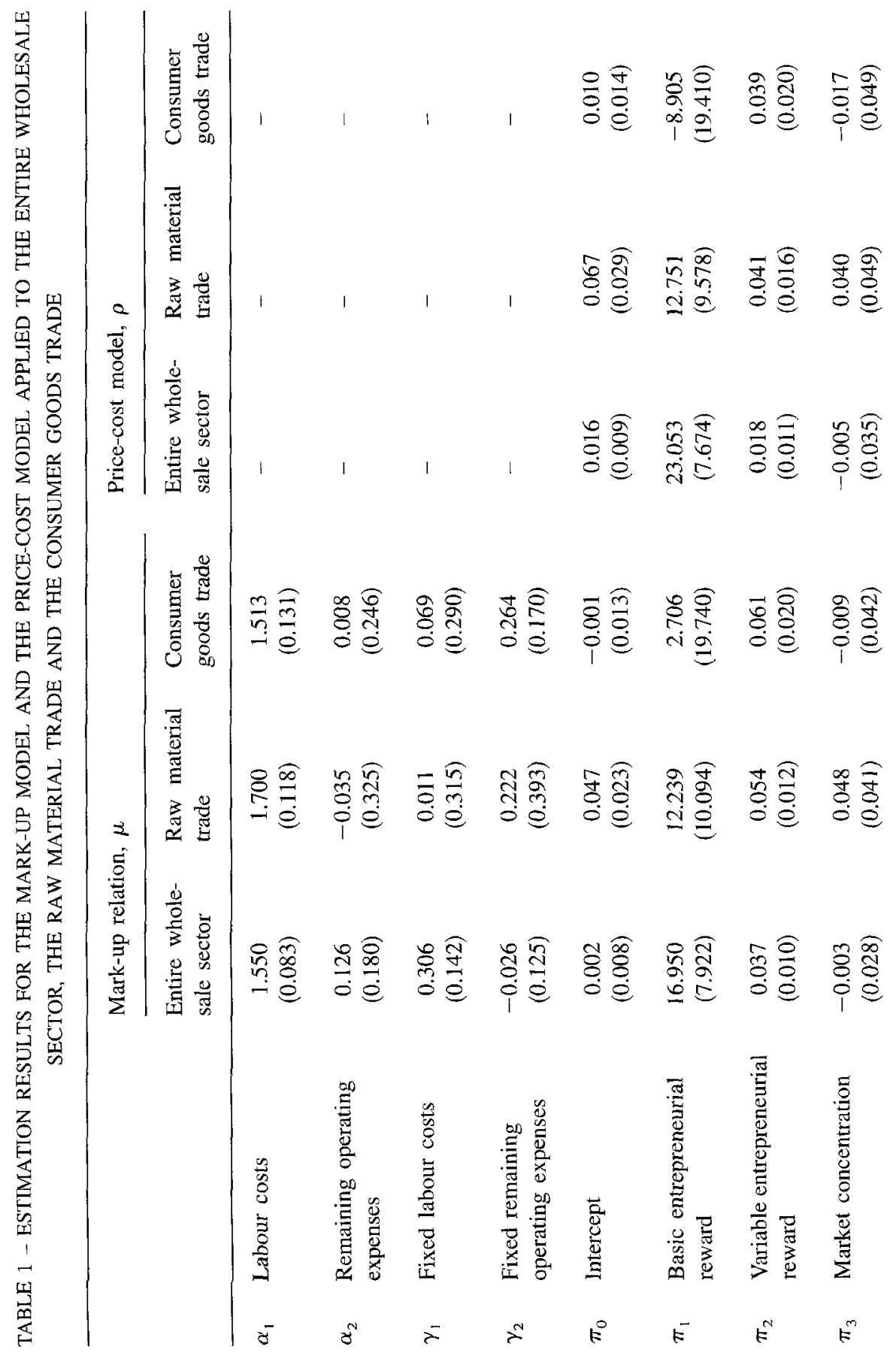




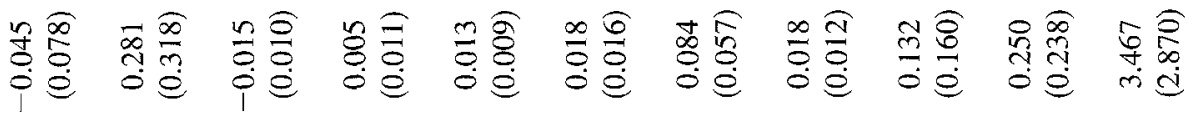

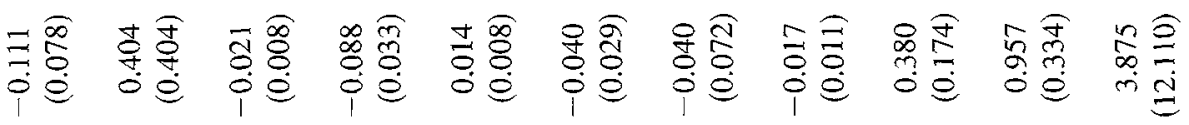

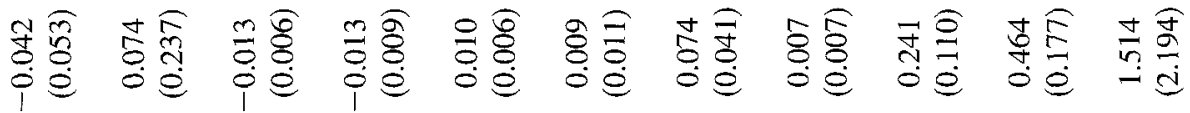

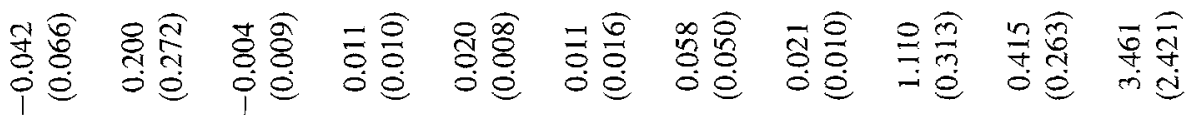

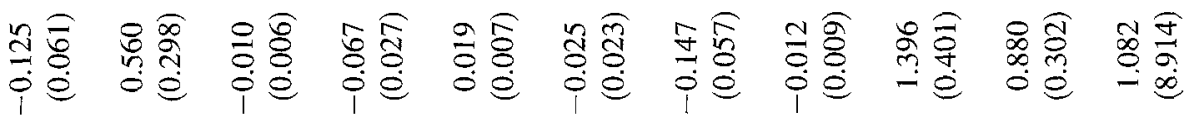

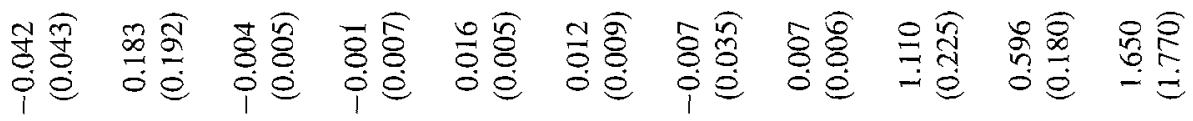

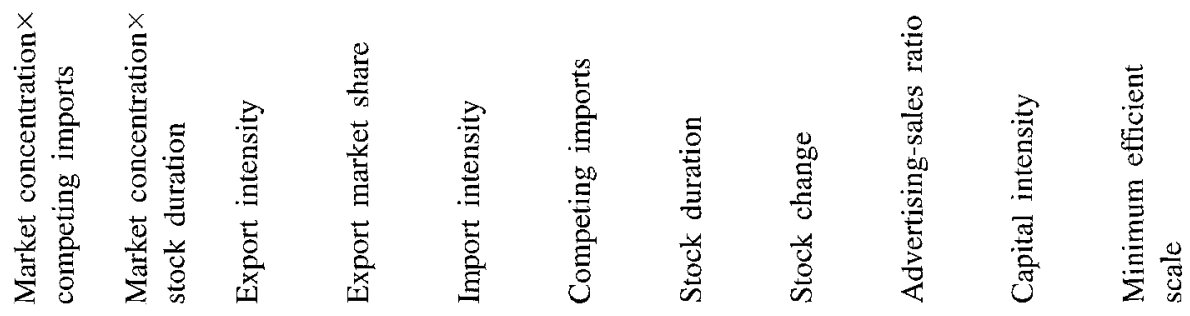

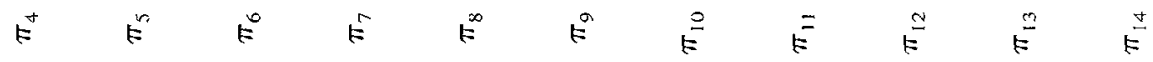




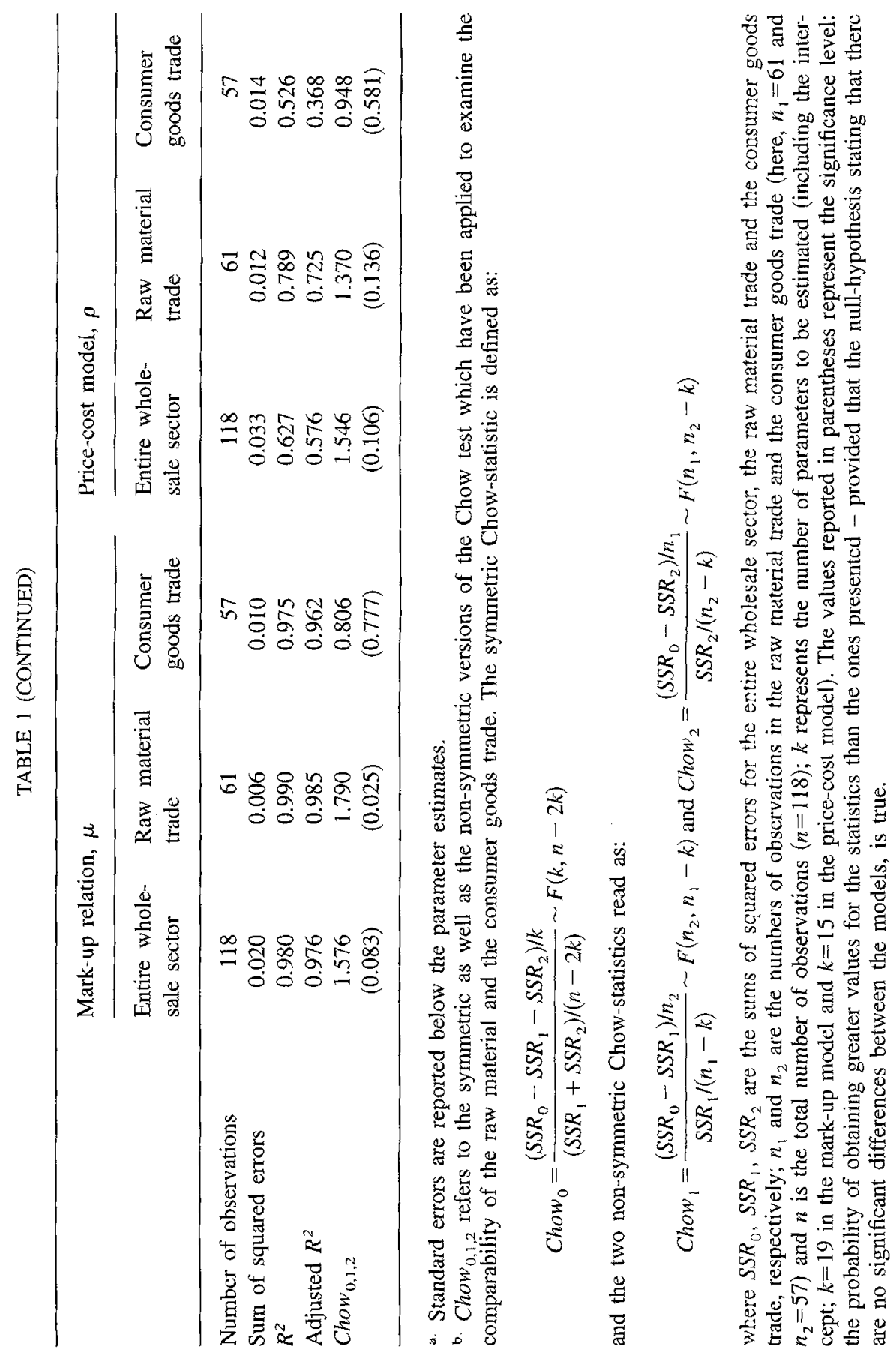


dently of the scale of operations and the existence of minimum capital requirements which perfectly suits the flexible nature of wholesaling. Two factors which do affect wholesale margins are international trade and inventory policy; we shall discuss these factors below.

In the case of the raw material trade, extensive export activities and large export market shares appear to be associated with more competitive price behaviour $\left(\hat{\pi}_{6}, \hat{\pi}_{7}<0\right)$. This is in line with the limited opportunities of Dutch wholesale merchants to differentiate between the home and foreign markets. The absence of significant export effects in the case of the consumer goods trade is likely to be caused by the compensating influence of more favourable conditions to differentiate the wholesale product. Intensive import activities are seen to enhance trade margins $\left(\hat{\pi}_{8}>0\right)$ in both sub-sectors, which indeed points at a less elastic demand for (wholesale intervention to import) foreign goods or at a widespread existence of exclusive sales contracts with foreign suppliers. The impact of competing imports is only observed in combination with market concentration: the more concentrated the market, the greater the pressure on wholesale margins emerging from competing imports $\left(\hat{\pi}_{4}<0, \hat{\pi}_{9} \approx 0\right)$, which accords with our expectations. International trade is thus seen to be associated with competitive export markets and with a comparatively less elastic domestic demand for foreign goods.

Furthermore, wholesale margins are sensitive to inventory behaviour. Again, the results differ between the raw material and the consumer goods trade. In the case of the raw material trade, trade margins are found to depend on the average stock duration. Here, the net impact of the stock duration, $\partial \mu / \partial V=$ $-0.147+0.560 H H$, implies (1) that the strategic importance of inventory keeping becomes more important when wholesale industries are more concentrated, as hypothesized by Rotemberg and Saloner (1989), and (2) that, on average, the stock duration has a negative effect (since the mean value of $H H$ is 0.11 ). This negative impact clearly contradicts our expectations. It may be explained by the inability of the applied stock duration measure to adequately represent the productenhancing aspect of wholesale inventories as elaborated previously by Van Dalen (1992). In the case of the consumer goods trade no significant effect of stock duration occurs. Instead, stock investments are found to have an unexpectedly positive influence on trade margins $\left(\hat{\pi}_{11}>0\right)$ implying that increases in the stock level, which are interpreted to go along with declines of demand, lead to greater profit rates. Two alternative explanations are the following. Firstly, investments in wholesale inventories may be launched to expand the number of commodity lines offered or to improve the quality of the assortment by shifting from low-quality low-priced goods to high-quality high-priced goods. The resulting upgrading of the wholesale product is likely to enhance the performance of wholesale merchants. Secondly, the causality of the profit/stock-change relation may be reversed: large current profits may induce traders to invest in inventories in expectation of a continuing high future demand and the associated rents, which, of 
course, yields a positive relation between trade margins and inventory increases. Future research efforts should take these alternatives into account.

\section{CONCLUDING REMARKS}

In this study, an empirical model is presented to explain variations in wholesale margins. The model is inspired by two widely accepted models of industry pricing: the behavioural full-cost mark-up model and the marginalist price-cost model. Furthermore, some attention is paid to the consequences of the nature of wholesale production for the interpretation and measurement of the determinants of wholesale profit margins.

Our empirical analysis gives rise to various conclusions. Firstly, the wholesale trade is not homogeneous with respect to pricing and consequently the raw material and the consumer goods trade should be studied separately. Secondly, the behavioural mark-up approach to industry pricing appears to be a more appropriate means to model wholesale pricing than the classical price-cost model. Thirdly, the pivoting role of human resources in wholesale operations is reflected by a more than proportional effect of labour costs on wholesale profit margins. By contrast, capital-intensive types of wholesale trade tend to be faced by more competitive price levels. Fourthly, wholesale margins are set independently of the scale of operations. This feature is reflected by the absence of a basic (scaleindependent) reward for small independent wholesale merchants as well as by the fact that the minimum firm size for efficient operation exerts no influence on the height of wholesale margins. Fifthly, the role of market concentration in wholesaling is limited. In the case of the raw material trade, the market concentration affects profit rates interactively with competing imports and stock duration, thereby emphasizing the strategic importance of these two factors. Sixthly, variations in profit margins (particularly in the case of the raw material trade) are mainly due to variations in the nature and degree of international trade and inventory behaviour.

Obviously, our single-equation approach treats wholesale pricing in an isolated manner. More elaborate models are required to give more appropriate descriptions of wholesale price behaviour. Specifications of the distributive costs may be added to the model in order to solve the endogeneity problem related with the costs of distribution. The endogeneity of variables like the import intensity, export intensity and market concentration might be treated in like manner. Specific efforts should be undertaken to endogenize the key role of inventories, which requires more insights into the determinants of inventory behaviour and the development of dynamic models of wholesale pricing. Such models would supplement existing pricing studies in manufacturing and retailing, increase knowledge about a seriously neglected party in the economy, and provide a starting point for more integrated analyses of the interrelationships between economic sectors. 


\section{APPENDIX}

The data used in the analysis is based on the information of more than 7000 individual wholesale firms spanning the entire Dutch wholesale sector in 1986. Access to these data has been facilitated by the Dutch Central Bureau of Statistics. The individual wholesale firms are classified into more or less homogeneous clusters on the basis of two criteria: type of merchandise and position in the distribution channel. The three digit SBI-code, the Dutch counterpart of the SIC, is used to classify firms according to similarities in commodity assortment, amounting to 18 classes. In addition, wholesale businesses are classified according to their economic activities, which yields seven types of traders:

1. importers/exporters: traders importing more than $50 \%$ of their total purchases and selling more than $50 \%$ of their merchandise abroad,

2. importers: traders importing more than $75 \%$ of their total purchases,

3. exporters: traders exporting more than $75 \%$ of their merchandise,

4. wholesale merchants selling more than $75 \%$ to domestic manufacturers,

5. wholesale merchants selling more than $75 \%$ to domestic retailers,

6. Wholesale merchants selling more than $75 \%$ to other domestic businesses,

7. remaining traders (not classified elsewhere).

These seven criteria are applied in the above order so as to overcome the problem that types of traders are not mutually exclusive. The order in which firms are classified is obviously important, since it shapes the process of classification (to some extent) and will consequently affect the estimations results. The current order of classification is based on the following considerations: (1) selling and buying in international markets requires specific skills and should therefore be distinguished from pure domestic trade and (2) notable varieties may occur in the distributive activities associated with international trade on the one hand and domestic trade on the other. Future explorations may consider to analyze the sensitivity of the results for variations in the classification order.

The confidential nature of the data does not allow us to present information about individual observations. Instead, some numerical characteristics of the explanatory variables are presented. 


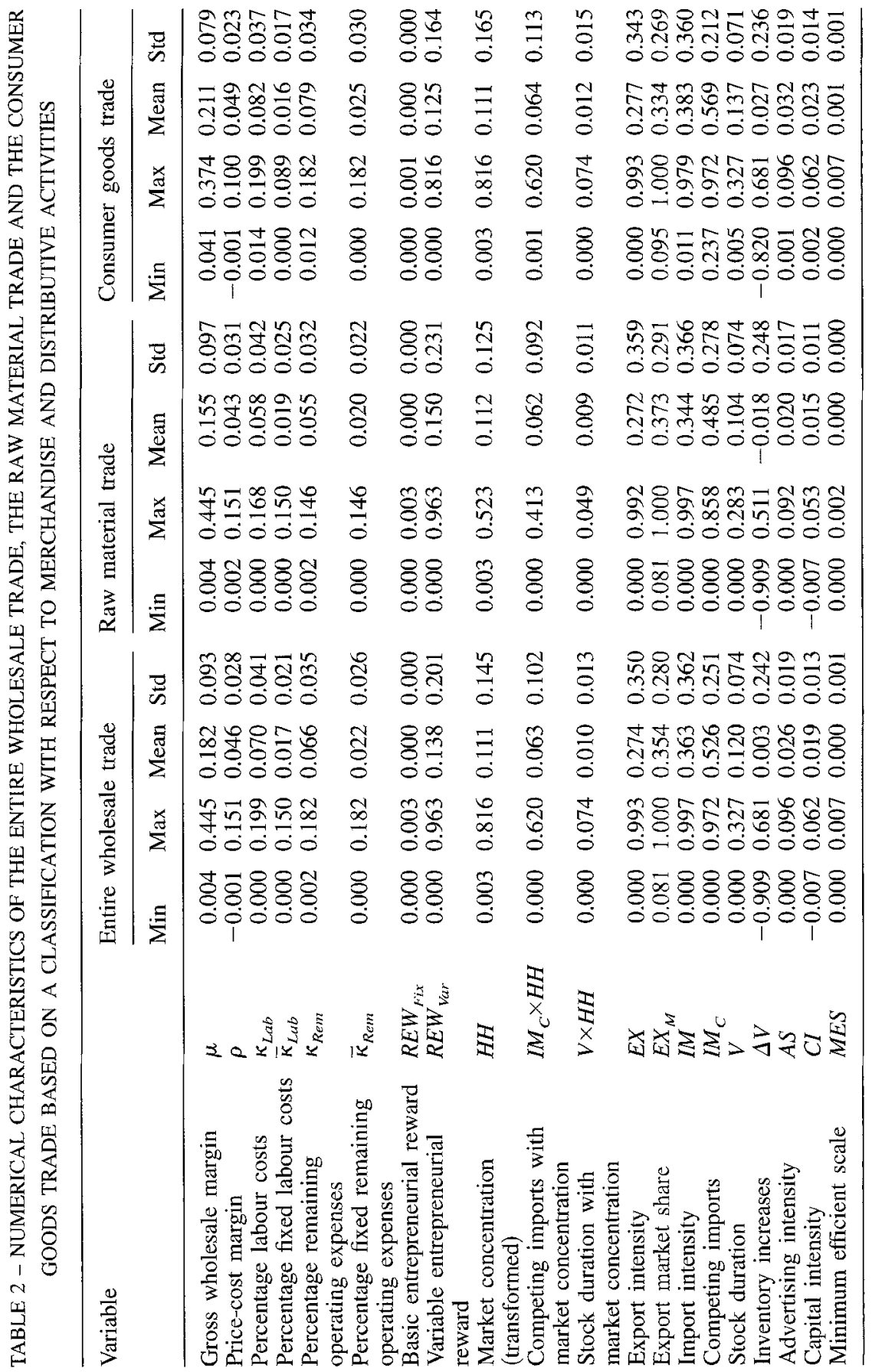




\section{REFERENCES}

Abel, A.B., 1985, 'Inventories, Stock-outs, and Production Smoothing,' Review of Economic Studies, 52, pp. 283-293.

Amihud, Y. and H. Mendelson, 1983, 'Price Smoothing and Inventory,' Review of Economic Studies, 50, pp. 87-98.

Andrews, P.W.S., 1949, Manufacturing Business, London, MacMillan.

Ashley, R.A. and D. Orr, 1985, 'Further Results on Inventories and Price Stickiness,' American Economic Review, 75, pp; 964-975.

Bain, J.S., 1951, 'The Relation of Profit Rate to Industry Concentration in American Manufacturing 1936-1940, Quarterly Journal of Economics, 65, pp. 293-324.

Baumol, W.J. and R.D. Willig, 1981, 'Fixed Costs, Sunk Costs, Entry Barriers and Sustainability of Monopoly,' Quarterly Journal of Economics, 101, pp. 405-432.

Baumol, W.J., J.C. Panzar and R.D. Willig, 1982, Contestable Markets and the Theory of Industry Structure, New York, Harcourt Brace Jonvanovich.

Beckman, Th.N. and N.H. Engle, 1949, Wholesaling: Principles and Practice, revised edition, New York, Ronald Press Company.

Blanchard, O.J., 1983, 'The Production and Inventory Behavior of the American Automobile Industry,' Journal of Political Economy, 91, pp. 365-400.

Blinder, A.S., 1982, 'Inventories and Sticky Prices: More on the Micro Foundations of Macro Economics,' American Economic Review, 72, pp. 334-348.

Blinder, A.S., 1986, 'Can the Production Smoothing Model of Inventory Behaviour Be Saved?', Quarterly Journal of Economics, 101, pp. 431-453.

Bucklin, L.P., 1972, Competition and Evolution in the Distributive Trades, Englewood Cliffs, N.J., Prentice Hall inc.

Caves, R.E., 1985, 'International Trade and Industrial Organization: Problems Solved and Unsolved,' European Economic Review, 28, pp. 377-395.

Caves, R.E., J. Khalilzadeh-Shirazi and M.E. Porter, 1975, 'Scale Economies in Statistical Analyses of Market Power,' Review of Economics and Statistics, 57, pp. 133-140.

Chou, T.-C., 1986, 'Concentration, Profitability and Trade in a Simultaneous Equation Analysis: The Case of Taiwan,' Journal of Industrial Economics, 34, pp. 429-443.

Clarke, R., S. Davies and M. Waterson, 1984, 'The Profitability-concentration Relation: Market Power or Efficiency,' Journal of Industrial Economics, 32, pp. 435-450.

Collins, N.R. and L.E. Preston, 1967, 'Price-cost Margins and Industry Structure,' Review of Economics and Statistics, 49, pp. 271-286.

Comanor, W.S. and T.A. Wilson, 1967, 'Advertising, Market Structure and Performance,' Review of Economics and Statistics, 49, pp. 343-340.

Cowling, K, 1976, 'On the Theoretical Specification of Industrial Structure Performance Relationships,' European Economic Review, 8, pp. 1-14.

Cowling, K. and M. Waterson, 1976, 'Price-cost Margins and Market Structure,' Economica, 43, pp. $267-274$.

Cubbin, J.S., 1988, Market Structure and Performance: The Empirical Research, Chur, Harwood Academic Publishers.

Cyert, R.M. and J.G. March, 1963, A Behavioral Theory of the Firm, Englewood Cliffs, N.J., Prentice Hall.

Dalen, J. van, J. Koerts and A.R. Thurik, 1990, 'The Measurement of Labour Productivity in Wholesaling,' International Journal of Research in Marketing, 7, pp. 21-34. 
Dalen, J. van and A.R. Thurik, 1991, 'Labour Productivity and Profitability in the Dutch Exporting Flower Trade,' Small Business Economics, 3, pp. 131-144.

Dalen, J. van, 1992, Quantitative Studies in Wholesaling, Ph.D. thesis, Erasmus University, Rotterdam.

Domowitz, I., R.G. Hubbatd and B.C. Petersen, 1986, 'Business Cycles and the Relationship between Concentration and Price-cost Margins,' Rand Journal of Economics, 17, pp. 1-17.

Eichenbaum, M.S., 1984, 'Rational Expectations and the Smoothing Properties of Inventories of Finished Goods,' Joumal of Monetary Economics, 1, pp. 55-70.

Eijkhout, M.P. and J. van Dalen, 1990, 'Een margemodel voor de groothandel,' in: CBS Select 6: Statistical Essays, pp. 75-90, Voorburg, The Netherlands Central Bureau of Statistics.

Esposito, L. and F.F. Esposito, 1971, 'Foreign Competition and Domestic Industry Profits,' Review of Economics and Statistics, 53, pp. 343-353.

Geroski, P.A., 1981, 'Specification and Testing the Profits-concentration Relationship: Some Experiments for the UK,' Economica, 48, pp. 279-288.

Ghellinck, E. de, P.A. Geroski and A. Jacquemin, 1988, 'Inter-industry Variations in the Effect of Trade on Industry Performance,' Journal of Industrial Economics, 37, pp. 1-19.

Glejser, H., A. Jacquemin and J. Petit, 1980, 'Exports in an Imperfect Competitive Framework: An Analysis of 1446 Exporters,' Quarterly Journal of Economics, 94, pp. 507-524.

Hall, R.L. and C.J. Hitch, 1939, 'Price Theory and Business Behaviour,' Oxford Economic Papers, 2, pp. $12-45$.

Hay, G.A., 1972, 'The Dynamics of Firm Behavior under Alternative Cost Structures,' American Economic Review, 62, pp. 403-413.

Hutchinson, R.W., 1981, 'Price-cost Margins and Manufacturing Industry Structure,' European Economic Review, 16, pp. 247-267.

Jacquemin, A., E. de Ghellinck and C. Huveneers, 1980, 'Concentration and Profitability in a Small Open Economy,' Journal of Industrial Economics, 29, pp. 131-144.

Khalilzadeh-Shirazi, J., 1974, 'Market Structure and Price-cost Margins in United Kingdom Manufacturing Industries,' Review of Economics and Statistics, 56, pp. 67-76.

Khan, J.A., 1987, 'Inventories and the Volatility of Production,' American Economic Review, 77, pp. $667-679$.

Koutsoyiannis, A., 1980, Modern Microeconomics, 2nd ed., London, MacMillan Press.

Lyons, B., 1981, 'Price-cost Margins, Market Structure and International Trade,' in: D. Currie, D. Peel and W. Peters (eds.), Microeconomic Analysis: Essays in Microeconomics and Economic Development, London, Croom Helm.

Martin, S., 1984, 'Structure and Performance of the US Wholesale Trade,' Managerial and Decision Economics, 5, pp. 160-167.

Martin, S., 1988, Industrial Economics: Economic Analysis and Public Policy, New York, MacMillan. Marvel, H.P., 1980, 'Foreign Trade and Domestic Competition,' Economic Inquiry, 18, pp. 102-122. Means, G.C., 1962, The Corporate Evolution in America, New York, Crowell-Collier.

Mills, E.S., 1957, 'The Theory of Inventory Decisions,' Econometrica, 25, pp. 222-238.

Nooteboom, B., 1980, Retailing: Applied Analysis in the Theory of the Firm, Amsterdam, J.C. Gieben. Nooteboom, B., 1982, 'A New Theory of Retailing Costs,' European Economic Review, 17, pp. 163186.

Nooteboom, B., 1985, 'A Mark-up Model of Retail Margins,' Applied Economics, 17, pp. 647-667.

Nooteboom, B., 1987, 'Estimation of Threshold Costs in Service Industries,' Service Industries Journal, pp. 65-76. 
Nooteboom, B. and A.R. Thurik, 1985, 'Retail Margins During Recession and Growth,' Economics Letters, 17, pp. 281-284.

Pagoulatos, E. and R. Sorenson, 1976, 'Foreign Trade, Concentration and Profitability in Open Economies,' European Economic Review, 8, pp. 255-267.

Phillips, A., 1976, 'A Critique of Empirical Studies of Relations Between Market Structure and Profitability,' Journal of Industrial Economics, 24, pp. 241-249.

Prince, Y.M. and A.R. Thurik, 1992, 'Price-cost Margins in Dutch Manufacturing: Effects of Concentration, Business Cycle and International Trade,' De Economist, 140, pp. 309-335.

Pugel, T.A., 1978, International Market Linkages and U.S. Manufacturing: Prices, Profits and Patterns, Cambridge, Ballinger Co.

Reagen, P.B., 1982, 'Inventory and Price Behaviour,' Review of Economic Studies, 49, pp. 137-142.

Rosenbaum, D.I., 1989, 'An Empirical Test of the Effect of Excess Capacity in Price Setting, Capacity Constrained Supergames,' International Journal of Industrial Organization, 7, pp. 231-241.

Rotemberg, J.J. and G. Saloner, 1989, 'The Cyclical Behavior of Strategic Inventories,' Quarterly Journal of Economics, 104, pp. 73-97.

Scherer, F.M. and D. Ross, 1990, Industrial Market Structure and Economic Performance, Third edition, Boston, Houghton Mifflin Company.

Schmalensee, R., 1989, 'Inter-industry Studies of Structure and Performance,' in: R. Schmalensee and G.O. Willig (eds.), Handbook of Industrial Organization II, Amsterdam. Elsevier Science Publishers.

Silberston, A., 1970, 'Surveys of Applied Economics: Price Behaviour of Firms,' Economic Journal, 80 , pp. 511-582.

Stålhammer, N.-O., 1991, 'Domestic Market Power and Foreign Trade: The Case of Sweden,' International Journal of Industrial Organization, 9, pp. 407-424.

Stigler, G.J., 1964, 'A Theory of Oligopoly,' Journal of Political Economy, 72, pp. 44-61.

Strickland, A.D. and L.W. Weiss, 1976, 'Advertising, Concentration and Price-cost Margins,' Journal of Political Economy, 84, pp. 1109-1121.

Thurik, A.R., 1984, Quantitative Analysis of Retail Productivity, Delft, Meinema.

Thurik, A.R., 1986, 'Productivity in Small Business: An Analysis Using African Data,' American Journal of Small Business, 11, pp. 27-42.

Waterson, H., 1984, Economic Theory of the Industry, Cambridge, Cambridge University Press.

West, K.D., 1986, 'A Variance Bounds Test of the Linear Quadratic Inventory Model,' Journal of Political Economy, 94, pp. 374-401.

Witteloostuijn, A. van, 1988, 'Maximising and Satisficing: Opposite or Equivalent Concepts?,' Journal of Economic Psychology, 9, pp. 289-313.

Witteloostuijn, A. van, 1992, "Theories of Competition and Market Performance: Multimarket Competition and the Source of Potential Entry,' De Economist, 140, pp. 109-139.

Woestijne, W.J. van de, 1982, Functie en functievervulling van de binnenlandse goederenhandel, 's Gravenhage, Verbond van de Nederlandse Groothandel. 


\section{Summary}

\section{WHOLESALE PRICNG IN A SMALL OPEN ECONOMY}

This paper addresses the empirical analysis of wholesale profit margins using data of the Dutch wholesale sector, 1986. At the heart of the analysis is the typical nature of wholesale production: wholesalers do not produce a tangible product, but offer a service capacity. This has an immediate impact on the identification, interpretation and measurement of determinants of profit variations. A model is set up to explain variations in wholesale profit margins, which is inspired by two widely applied approaches to industry pricing: the behavioural mark-up model and the marginalist price-cost model. 